\title{
Identification of a Subtype of Poorly Differentiated Invasive Ductal Carcinoma of the Breast Based on Vimentin and E-cadherin Expression
}

\section{Identificação de um subtipo pouco diferenciado de carcinoma ductal invasivo de mama, baseado na expressão da vimentina e E-caderina}

\author{
Leonardo Fleury Orlandini ${ }^{1}$ Francisco José Cândido dos Reis ${ }^{1}$ Willian Abraham da Silveira \\ Marcelo Guimarães Tiezzi ${ }^{1}$ Jurandyr Moreira de Andrade ${ }^{1}$ Alfredo Ribeiro-Silva ${ }^{1}$ Ryan Deaton ${ }^{2}$ \\ Maarten Bosland ${ }^{2}$ Daniel Guimarães Tiezzi ${ }^{1}$ \\ 1 Breast Disease Division, Department of Gynecology and Obstetrics, \\ School of Medicine, Hospital das Clínicas da Universidade de São \\ Paulo, Ribeirão Preto, SP, Brazil \\ 2 University of Illinois at Chicago, Chicago, IL, United States \\ Address for correspondence Daniel Guimarães Tiezzi, PhD, Breast \\ Disease Division, Department of Gynecology and Obstetrics, School of \\ Medicine, Hospital das Clínicas da Universidade de São Paulo, Av \\ Bandeirantes, 3900, Monte Alegre, Ribeirão Preto, SP, 14040-900, \\ Brasil (e-mail: dtiezzi@usp.br).
}

Rev Bras Ginecol Obstet 2018;40:779-786.
Objective The use of molecular markers can identify a subgroup of tumors with distinct recurrence patterns. The present study aimed to characterize the immunohistochemical expression of vimentin (VIM), of E-cadherin (CDH1), and of cytokeratin 5 (CK5) in patients with invasive ductal carcinomas (IDCs).

Methods We have constructed a tissue microarray (TMA) from 87 patients with IDC of the breast. Immunohistochemistry (IHC) was performed to study the expression of estrogen and progesterone receptors (ER and $\mathrm{PgR}$ ), human epidermal growth factor receptor 2 (HER2), VIM, CDH1, CK5, and Ki67. The tumors were classified as luminal A and $B(n=39)$, HER2 enriched $(n=25)$, and triple-negative (TNBC) $(n=23)$, based on the IHC expression.

Results We have observed that luminal $A$ and $B$ tumors lack the $\mathrm{VIM}^{+} / \mathrm{CDH} 1^{\text {-llow }}$ phenotype. This phenotype was observed in $16.5 \%$ of the HER $2+$ tumors and in $60 \%$ of the TNBC tumors $(p=0.0001)$. Out of a total of 20 TNBC tumors, the CK5 (basal-like marker) was positive in 11 of them. The $\mathrm{VIM}^{+} / \mathrm{CDH} 1^{- \text {/low }}$ phenotype was observed in 5 CK5+ TNBC tumors (45\%) and in 7 out of 9 CK5- TNBC tumors $(78 \%)(p=0.02)$. The median Ki67 index in the $\mathrm{VIM}^{+} / \mathrm{CDH}^{- \text {-low }}$ tumors was 13.6 (range: 17.8-45.4) compared with 9.8 (range: $4.1-38.1)$ in other tumors $(p=0.0007)$. The presence of lymph node metastasis was less frequent in patients with $\mathrm{VIM}^{+} / \mathrm{CDH} 1^{- \text {-low }}$ tumors $(23 \%$ versus $61 \% ; X^{2}$ test; $p=0.01$ ).

Conclusion Our findings suggest that the expression of VIM and CDH1 can identify a subset of IDCs of the breast with a mesenchymal phenotype associated with poor prognosis, high-grade lesion, and high mitotic index. received

April 19, 2018

accepted

August 9, 2018

published online

October 25, 2018
DOI https://doi.org/

10.1055/s-0038-1673700. ISSN 0100-7203.
Copyright $(2018$ by Thieme Revinter

Publicações Ltda, Rio de Janeiro, Brazil
License terms

(c) (1) 


\section{Resumo}

\author{
Palavras-chave \\ - câncer de mama \\ - transição epitelial- \\ mesenquimal \\ - vimentina \\ - e-caderina \\ - fatores prognósticos
}

Objetivo O uso de marcadores moleculares pode identificar subtipos tumorais com diferentes taxas de recidiva. O objetivo do presente estudo é caracterizar a expressão imunohistoquímica da vimentina (VIM), da E-caderina ( $\mathrm{CDH} 1)$ e de $\mathrm{CK} 5$ em pacientes com carcinoma ductal invasivo (CDI) da mama.

Métodos Utilizamos uma matriz de amostras teciduais (TMA, na sigla em inglês) de 87 pacientes com CDI da mama. Para avaliar a expressão dos receptores de estrogênio (RE) e receptores de progesterona (RP), HER2, VIM, CDH1, CK5 e Ki67, utilizamos imunohistoquímica. Os tumores foram classificados como luminal A e $\mathrm{B}(n=39)$, HER2 $+(n=25)$ e triplo negativo (TNBC) $(n=23)$.

Resultados Foi observado que tumores luminais $A$ e $B$ não expressaram o fenótipo $\mathrm{VIM}^{+} / \mathrm{CDH}^{- \text {-llow }}$. Este fenótipo foi observado em 16,5\% dos tumores HER2+e em 60\% dos tumores TNBC $(p=0,0001)$. Dos 20 tumores TNBC, a CK5 (marcador de tumor basalóide) foi super expressa em 11 amostras. O fenótipo $\mathrm{VIM}^{+} / \mathrm{CDH} 1^{\text {-llow }}$ foi observado em 5 tumores CK5+ TNBC (45\%) e em 7 dos 9 tumores CK5- TNBC (78\%) $(p=0,02)$. A expressão média de Ki67 nos tumores $\mathrm{VIM}^{+} / \mathrm{CDH}^{- \text {/low }}$ foi 13.6 (amplitude de 17,8 a 45,4) comparado com 9,8 (amplitude de 4,1 a 38,1) nos outros tumores $(p=0,0007)$. A presença de metástase linfonodal foi menor em tumores com fenótipo $\mathrm{VIM}^{+} / \mathrm{CDH} 1^{- \text {-low }}$ ( $23 \%$ contra $61 \%$; teste $X^{2} ; p=0,01$ ).

Conclusão Nossos achados sugerem que a expressão de VIM e CDH1 pode identificar um subtipo de CDI da mama com fenótipo mesenquimal associado a pior prognóstico, lesões de alto grau e alto índice mitótico.

\section{Introduction}

Based on its genomic profile, breast cancer can be classified in six subtypes (luminal A, luminal B, human epidermal growth factor receptor 2 (HER2)-enriched, basal-like, claudin-low, and normal-like). ${ }^{1,2}$ This classification stratifies patients with adverse prognostic characteristics, and the basal-like and claudin-low subtypes confer the shortest overall survival. ${ }^{3-6}$ Immunohistochemical phenotyping based on estrogen and progesterone receptors (ER and PgR), HER2, and Ki67 expression has been proposed as an alternative to classify breast cancer into different subtypes. According to this immunophenotyping approach, breast cancer can be divided into luminal $A$ (HR + , HER2-, low Ki67 index), luminal B (HR+ with HER2+ or HER2- plus high Ki67 index), HER2-enriched(HR-, HER2 + ) and triple negative (TNBC) (HR- and HER2-)..$^{7-10}$

Triple negative tumors tend to have a worse prognosis than luminal A, luminal B, and HER2-enriched tumors, and no specific targeted TNBC therapy has been developed yet. ${ }^{11-14}$ Although TNBC has been characterized as a pathological entity, there is significant biological heterogeneity within these tumors. ${ }^{13,15}$ The basal-like phenotype is reported as the main TNBC subtype. ${ }^{8,16,17}$ However, all the other molecular subtypes can occur. ${ }^{16,17}$ The use of immunohistochemistry (IHC) to identify different subgroups of TNBC tumors has been proposed. Cytokeratin 5 (CK5) and epidermal growth factor receptor (EGFR) expressions have been reported as markers of basal-like carcinomas. ${ }^{7,8,14,15,18}$ In fact, CK5 expression has been reported to be the most accurate basal-like marker., 19-22 Breast cancers that have arisen from basal cells are supposed to have a mesenchymal phenotype. ${ }^{17,23,24}$ The claudin-low group lacks cell-cell junction proteins, and has features resembling the epithelial-mesenchymal transition (EMT) activation. ${ }^{2,13,17,25}$ Additionally, some studies have suggested that there is a subgroup with a quintuple-negative profile (HR-, HER2-, CK5-, and EGFR-) that exhibits a worse prognosis when compared with CK5+ or EGFR+ TNBC. ${ }^{18,26}$ Thus, the use of EMT markers can identify an undifferentiated subgroup with a possibly highly aggressive clinical behavior., ${ }^{4,17,27}$

Most investigated and reported EMT markers include the Ecadherin (CDH1), a cell surface protein responsible for the adhesion of epithelial cells. Downregulation in CDH1 is highly associated with EMT, and partial or total loss of $\mathrm{CDH} 1$ expression is associated with more aggressive behavior and poor prognosis. ${ }^{28-30}$ Often coupled with low CDH1expression, vimentin (VIM), a type III intermediate filament protein that is expressed in mesenchymal cells, has been used to investigate EMT activation in epithelial tissues. The VIM expression in epithelial cells is associated with a migratory phenotype and consequent invasiveness and metastasis. ${ }^{29,31-33}$ The aim of the present study was to determine the VIM and CDH1 expression in invasive ductal carcinomas (IDCs) of the breast, and to analyze their association with CK5 expression and clinical and pathological features.

\section{Methods}

\section{Sample Selection}

We have selected all patients ( $n=175$ ) with IDC of the breast subjected to surgery at Hospital das Clínicas of the Faculdade 
de Medicina de Ribeirão Preto between January 2005 and December 2007. The selection was based on the histological and immunohistochemical diagnosis in the files of the patients. The staging system was based on the American Joint Committee on Cancer ( $7^{\text {th }}$ edition) classification. We have used pathological staging for patients subjected to primary surgery, and clinical staging in cases of neoadjuvant treatment. According to the IHC reports, 27 IDCs were TNBC, 39 were HER2 + (with a score of $3+$ ), 36 were HER2+ (score of $2+$ ), and 73 were $\mathrm{HR}+$ (for estrogen or progesterone receptors) and HER2- (with a score of 0 or $1+$ ). We were able to retrieve 94 paraffin blocks, and 82 were suitable for tissue microarray (TMA) construction. The total sample comprised 24 TNBCs, 9 HER + and HR-, 14 HER2 + and HR + , and 35 HR + and HER2-. All samples were reevaluated, and the histological diagnosis and tumor grade were reported. - Table 1 summarizes the characteristics of the patients.

Table 1 Characteristics of 82 patients with invasive ductal carcinoma of the breast

\begin{tabular}{|l|l|}
\hline Parameter & $\mathbf{n}=\mathbf{8 2}$ \\
\hline Age (mean \pm SD) & $54.4 \pm 13.1$ \\
\hline Menopausal status & \\
\hline Pre & 29 \\
\hline Post & 53 \\
\hline Clinical Stage & \\
\hline I & 8 \\
\hline IIA & 43 \\
\hline IIB & 16 \\
\hline IIIA & 8 \\
\hline IIIB & 6 \\
\hline IV & 1 \\
\hline Histological grade & \\
\hline 1 & 9 \\
\hline 2 & 49 \\
\hline 3 & 24 \\
\hline Neoadjuvant treatment & \\
\hline Chemotherapy & 28 \\
\hline Hormone therapy & 39 \\
\hline No & 33 \\
\hline Estrogen receptor & \\
\hline Positive & \\
\hline Negative & \\
\hline Progesterone receptor & \\
\hline Positive & \\
\hline Negative & \\
\hline HER2 & \\
\hline Positive & \\
\hline Negative & \\
\hline
\end{tabular}

Abbreviation: HER2, human epidermal growth factor receptor 2.

\section{Tissue Microarray}

Core biopsies (diameter $=1 \mathrm{~mm}$ ) were punched from 2 representative areas of each tumor of each of the 87 donor paraffin blocks and arrayed into a new recipient paraffin block using a manual tissue arrayer (Beecher Instruments, Sun Prairie, WI, USA). Three $1 \mu \mathrm{m}$-thick sections were cut from a tissue microarray (TMA) paraffin block using a paraffin tape-transfer system (Instrumedics Inc., Saint Louis, MO, USA). The slides were dipped in paraffin to prevent oxidation. One section was stained with hematoxylin and eosin (H\&E) to confirm the presence of the tumor by light microscopy.

\section{Immunohistochemistry}

The immunohistochemical staining was performed using the Novolink Max Polymer Detection System (Leica Biosystems, Wetzlar, Germany). The sections were deparaffinized in xylene and rehydrated through a series of graded alcohols. The endogenous peroxidase activity was blocked for 30 minutes in a solution containing $0.3 \%$ of hydrogen peroxide to block non-specific immunoassaying. The sections were then placed in a $10 \mathrm{mM}$ citrate buffer and submitted to heat retrieval using a vapor lock for 40 minutes. After the antigen retrieval, the specimens were allowed to cool for 30 minutes, and then incubated at $4^{\circ} \mathrm{C}$ overnight with a primary antibody. The dilution and source of the primary antibodies used in the present study were: anti-human ER (1:100, clone 6F11) (Leica Biosystems, Wetzlar, Germany), anti-human PgR (1:100, clone 1A6) (Leica Biosystems, Wetzlar, Germany), anti-human-Ki67 (1:200) (Leica Biosystems, Wetzlar, Germany), anti-human CK5 (HPA024467, 1:100) (Sigma-Aldrich, St. Louis, MO, USA), anti-human vimentin (1:100, clone V9) (Biocare Medical, Pacheco, CA, US), and anti-human CDH1 (1:50, clone HECD-1) (Biocare Medical, Pacheco, CA, USA). After overnight incubation with the primary antibody, the slides were incubated with a postprimary solution for 30 minutes and then incubated with the polymer for another 30 minutes (both provided by the Novolink Max Polymer Detection System). The reaction was developed with diaminobenzidine (DAB), followed by hematoxylin counterstaining. The slides were then dehydrated in an ethanol series and mounted with Permount (Fischer, Fair Lawn, NJ, USA). The DAKO Herceptest (Agilent Technologies, Santa Clara, CA, USA) was used for HER2 protein staining following the protocol of the manufacturer.

Digital analysis: In brief, the Ki67 TMA slide was scanned at $20 \times$ magnification on an Aperio Scanscope CS (Aperio Technologies Inc., Vista, CA, USA). The Aperio Scanscope CS is a whole-slide imaging system that scans entire tissue sections and registers the image stripes into one file. The image was uploaded onto an Aperio Spectrum Plus server, and then we used the TMA Laboratory module to break the image into its logical components of sectors, rows, columns, and cores. The Nuclear V9.1 (Aperio Technologies, Vista, CA) image analysis algorithms were used for the quantification of the Ki67 staining. In general, this algorithm begins by splitting the color data in the image into a maximum of 3-color channels. In this case, we separated the channels into a blue hematoxylin channel and a brown DAB channel. The 
remaining channel was left at its default red color and was ignored in the analysis. For nuclear staining of the Ki67 protein, the colocalization algorithm reports the percentage of positive cells within all cancer cells.

\section{Interpretation of Immunohistochemical Staining}

The cases were interpreted as positive for ER and PgR if the Allred score was $\geq 3 .{ }^{34}$ Marker Ki67 was considered positive if $>13 \%$ of the cancer cells in a core were stained (digital analysis). The expression of HER-2 was scored according to the degree and proportion of membrane staining as per the Herceptest protocol. The ER, PgR, and HER2 positive expression rates were $86.1 \%, 72.2 \%$, and $25 \%$, respectively. The tumors were then classified according to ER, PgR, Ki67, and HER2 protein expression as luminal A (ER + or PgR + , and HER2-), luminal B (ER + or $\operatorname{PgR}+$, with HER2 + or Ki67 $\leq 13 \%)$, HER2 + (ER- and PgR-, with HER2 + ), and TNBC (ER-, PgR-, and HER2-). Vimentin was considered positive if $>30 \%$ of the tumor cells in a core exhibited cytoplasmic brown DAB staining. E-cadherin was denomi- nated as $\mathrm{CDH} 1^{-/ \text {low }}$ if there was no membranous staining at all or if there were $>30 \%$ of tumor cells with no staining or discontinued membranous staining in a core. Due to missing cores on slides from the TMA block, the analysis of VIM and CDH1 expression was satisfactory in 73 samples; Ki67 and CK5 expression was satisfactory in 82 and 81 samples, respectively. The ER, PgR, and HER2 expression was analyzed in 82 samples. - Fig. 1 shows positive and negative expressions for VIM and CDH1.

\section{Statistical Analysis}

The expression of VIM and CDH1 proteins and other categorical variables were compared using the standard $X^{2}$ test or the Fisher exact test. The difference in the Ki67 staining index was evaluated using the median test, while the difference in age between groups was assessed using the $t$-test. The disease-free and overall survival interval was calculated from the date of diagnosis, and the survival curves were derived from Kaplan-Meier estimates and compared by logrank tests. The JMP version 10 software (SAS, Cary, NC, USA)

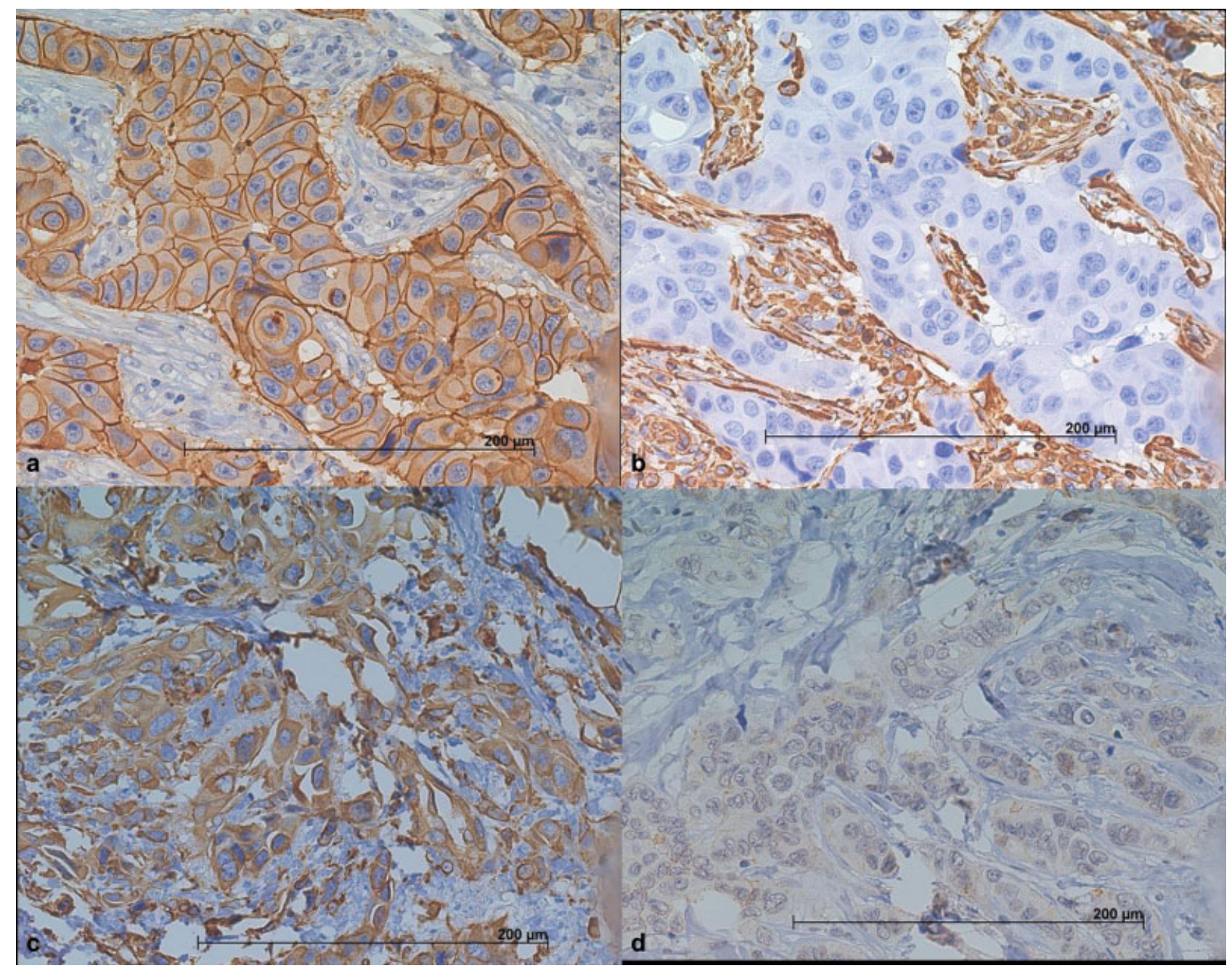

Fig. 1 Expression of vimentin (VIM) and E-cadherin ( $\mathrm{CDH} 1)$ in invasive ductal carcinoma of the breast. The figures a and b illustrate a grade 2, luminal A invasive ductal carcinoma with a strong positive membrane staining for CDH1 (a) and negative expression of VIM (b). Note the VIM expression in stromal cells and the complete lack of staining in epithelial malignant cells. Figures $\mathrm{c}$ and $\mathrm{d}$ illustrate a grade 3 , TNBC with VIM ${ }^{+} /$ $\mathrm{CDH} 1^{- \text {llow }}$ phenotype (vimentin positive in $\mathrm{c}$ and $\mathrm{CDH} 1$ negative in d). Note the positive cytoplasmic staining for vimentin. Expression of $\mathrm{CDH} 1$ is absent in cell membrane. 
was used for the statistical analyses. The significance was established as $p<0.05$ (two-sided).

\section{Results}

\section{Expression of CK5, VIM and CDH1 in IDCs}

According to the immunophenotyping performed on TMA, 30 samples were classified as luminal A, 19 as luminal B, 9 as HER2enriched, and 24 as TNBC. The CK5 expression was more frequent in TNBC tumors (13 out of 24 tumors, 54.2\%), and it was positive in 3 luminal A tumors (10\%), in 1 luminal B tumor (5.3\%), and only in $1(11 \%)$ HER2-enriched tumor $\left(x^{2}\right.$ test; $\left.p=0.0002\right)$. Vimentin was not expressed in luminal A and HER2-enriched tumors, but positive expression was observed in $71.4 \%$ of the TNBC tumors and in $5.3 \%$ of the luminal B tumors $\left(X^{2}\right.$ test; $\left.p<0.0001\right)$. The absence or reduction in $\mathrm{CDH} 1$ expression $\left(\mathrm{CDH} 1^{- \text {-low }}\right)$ was not observed in luminal B and in HER2 enriched tumors, but it was observed in $7.1 \%$ and $61.9 \%$ of the luminal A and TNBC tumors, respectively ( $x^{2}$ test; $p<0.0001$ ).

\section{$\mathrm{VIM}^{+}$(CDH1 ${ }^{- \text {llow }}$ phenotype in invasive ductal carcinomas (- Table 2)}

We have analyzed the combined expression of VIM and CDH1 and observed that luminal A, luminal B, and HER2-enriched tumors lack the $\mathrm{VIM}^{+} / \mathrm{CDH} 1^{-/ \text {low }}$ phenotype, whereas this phenotype was observed in $61.9 \%$ of the TNBC tumors $\left(x^{2}\right.$ test; $p<0.0001)$. The $\mathrm{VIM}^{+} / \mathrm{CDH}^{-/ \text {low }}$ phenotype was observed in 5 out of $15 \mathrm{CK} 5+$ TNBC tumors (33\%), and in 8 out of 57 CK5-TNBC tumors (14\%) (Fisher exact test; $p=0.13$ ). The median Ki67 index in $\mathrm{VIM}^{+} / \mathrm{CDH} 1^{- \text {llow }}$ tumors was 13.6 , compared with 9.8 in other tumors (median test; $p=0.0007$ ).

Comparing tumors with the $\mathrm{VIM}^{+} / \mathrm{CDH} 1^{-/ \text {low }}$ phenotype with the other tumors, there was no difference in the age, menopausal status, clinical stage, and the presence of lymph node invasion in the patients ( $X^{2}$ test; $p=1.0$ ). The frequency of lymph node metastases was lower in patients with $\mathrm{VIM}^{+} / \mathrm{CDH} 1^{- \text {llow }}$ tumors than in other tumors (- Table 2).

We have analyzed the disease-free and overall survival according to tumor subtypes, CK5 expression, and $\mathrm{VIM}^{+}$I $\mathrm{CDH} 1^{-/ \text {low }}$ phenotype. We did not find a significant difference in disease-free and overall survival between luminal A, luminal B, HER2-enriched, and TNBC tumors, and there was no association between CK5 expression and survival (data not shown). In patients with $\mathrm{VIM}^{+} / \mathrm{CDH}^{- \text {/low }}$ phenotype and non-VIM ${ }^{+} / \mathrm{CDH} 1^{-/ \text {low }}$ phenotype tumors, the 5-year disease-free survival rates were of $61.5 \%$ and $83.7 \%$, and the 5 -year overall survival rates were $51.2 \%$ and $83.5 \%$, respectively. - Fig. 2 shows the Kaplan-Meier curves for disease-free and overall survival according to the $\mathrm{VIM}^{+} \mid$ $\mathrm{CDH}^{- \text {/low }}$ phenotype, which were statically significant ( $p=0.02$ and $p=0.03$ [log-rank test], respectively).

\section{Discussion}

Breast cancer is a biologically and clinically heterogeneous disease. . $^{-3,5,7-10,15-17}$ This complexity is a key factor for treatment failure. ${ }^{1,10-12,35,36}$ Immunohistochemistry has been used to analyze the expression of specific proteins in
Table 2 Clinical and pathological characteristics of 73 invasive ductal carcinomas of the breast according to the $\mathrm{VIM}^{+} / \mathrm{CDH} 1^{- \text {/low }}$ phenotype

\begin{tabular}{|c|c|c|c|}
\hline & $\mathrm{VIM}^{+} / \mathrm{CDH} 1^{-/ l o w}$ & Other & p-value \\
\hline $\begin{array}{l}\text { Age } \\
(\text { mean } \pm S D)\end{array}$ & $55.9 \pm 16.1$ & $53.5 \pm 12.0$ & 0.6 \\
\hline \multicolumn{4}{|l|}{$\begin{array}{l}\text { Menopausal } \\
\text { status }\end{array}$} \\
\hline Pre & 5 & 23 & \\
\hline Post & 8 & 37 & 0.9 \\
\hline \multicolumn{4}{|l|}{ Clinical stage } \\
\hline 1 & 1 & 6 & \\
\hline II & 9 & 45 & \\
\hline III/IV & 3 & 9 & 0.7 \\
\hline \multicolumn{4}{|l|}{$\begin{array}{l}\text { Histological } \\
\text { grade }\end{array}$} \\
\hline 1 & 0 & 9 & \\
\hline 2 & 4 & 40 & \\
\hline 3 & 9 & 11 & 0.0009 \\
\hline \multicolumn{4}{|l|}{ Axillary status } \\
\hline Positive & 3 & 37 & \\
\hline Negative & 10 & 23 & 0.01 \\
\hline \multicolumn{4}{|l|}{$\begin{array}{l}\text { Estrogen } \\
\text { receptor }\end{array}$} \\
\hline Positive & 0 & 43 & \\
\hline Negative & 13 & 13 & $<0.0001$ \\
\hline \multicolumn{4}{|l|}{$\begin{array}{l}\text { Progesterone } \\
\text { receptor }\end{array}$} \\
\hline Positive & 0 & 42 & \\
\hline Negative & 13 & 18 & $<0.0001$ \\
\hline \multicolumn{4}{|l|}{ HER2 } \\
\hline Positive & 0 & 19 & \\
\hline Negative & 13 & 41 & 0.01 \\
\hline $\begin{array}{l}\text { Ki67 (median, } \\
\text { range) }\end{array}$ & $\begin{array}{l}13.6 \\
(17.8-45.4)\end{array}$ & $\begin{array}{l}9.8 \\
(4.1-38.1)\end{array}$ & 0.0007 \\
\hline \multicolumn{4}{|l|}{ CK5 } \\
\hline Positive & 5 & 10 & \\
\hline Negative & 8 & 49 & 0.13 \\
\hline \multicolumn{4}{|l|}{ Tumor subtype } \\
\hline Luminal A & 0 & 28 & \\
\hline Luminal B & 0 & 19 & \\
\hline HER2 enriched & 0 & 5 & \\
\hline TNBC & 13 & 8 & $<0.0001$ \\
\hline
\end{tabular}

Abbreviations: $\mathrm{CDH}$ 1, E-cadherin; CK5, cytokeratin 5; HER2, human epidermal growth factor receptor 2; SD, standard deviation; TNBC, triple-negative breast cancer; VIM, vimentin.

cancer cells to identify subsets of tumors with specific characteristics, enabling a personalized treatment. ${ }^{7-10,18,26}$ We have demonstrated that there is a subset of invasive breast carcinomas with characteristics of a mesenchymal $\mathrm{VIM}^{+} / \mathrm{CDH} 1^{- \text {llow }}$ phenotype, suggesting that the use of 
A

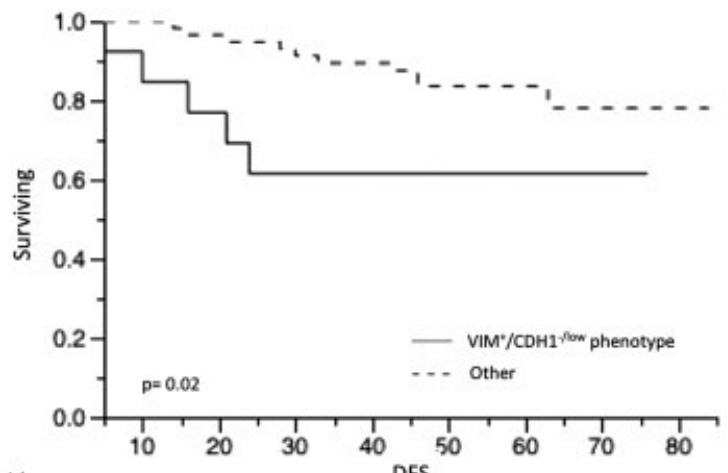

Number at risk

\begin{tabular}{|l|c|c|c|c|c|c|c|c|}
\hline VIM $^{*} / \mathrm{CDH}^{\text {-now }}$ & 13 & 12 & 10 & 9 & 7 & 5 & 3 & 2 \\
\hline Other & 60 & 59 & 56 & 52 & 49 & 35 & 19 & 10 \\
\hline
\end{tabular}

B

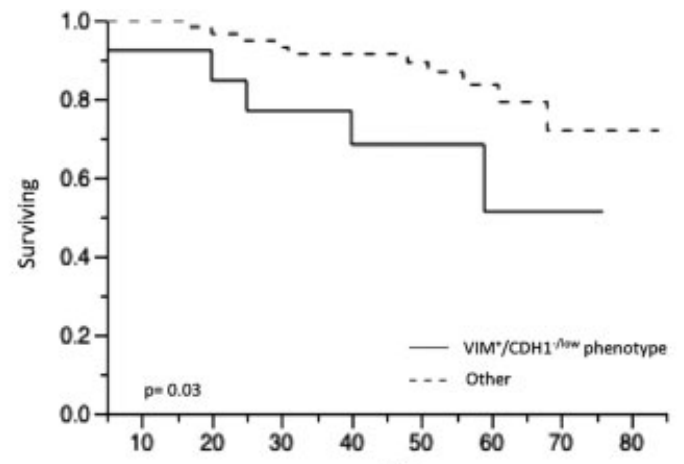

Number at risk
\begin{tabular}{|l|c|c|c|c|c|c|c|c|}
\hline $\mathrm{VIM}^{+} / \mathrm{CDH}^{\text {-how }}$ & 13 & 13 & 12 & 11 & 9 & 6 & 3 & 1 \\
\hline Other & 60 & 59 & 57 & 53 & 51 & 39 & 20 & 10 \\
\hline
\end{tabular}

Fig. 2 Disease-free (A) and overall survival (B) in 73 patients with invasive ductal carcinoma (IDC) of the breast according to the vimentin (VIM) and E-cadherin ( $\mathrm{CDH} 1)$ expression

mesenchymal markers may be important for therapeutic decisions.

Despite the fact there is yet no specific tumor marker to identify the basal-like subset of breast tumors, the development of a targeted therapy as a clinical approach to enhance systemic therapy has received great attention for breast cancer treatment. ${ }^{11,12,37-40}$ The acquisition of a mesenchymal phenotype by epithelial malignant cells is an important step to cancer invasion and metastasis. ${ }^{39-42}$ Some novel targeted therapies that interfere specifically with the EMT program are being developed. ${ }^{43-47}$ Triple negative tumors are considered a specific subtype of breast cancer with early recurrence and poor prognosis. ${ }^{9-11,14}$ Transcriptome analysis has demonstrated that basal-like breast carcinomas ex-

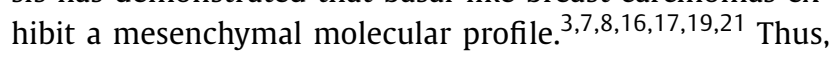
the use of an anti-EMT program therapy could be investigated in the treatment of TNBCs.

The use of CK5 has been proposed to identify a subset of TNBC tumors with a basal phenotype in some reports, demonstrating that CK5 expression in TNBCs could predict between 61 and 95\% of basal-like subtypes as defined by transcriptome analysis. ${ }^{20,48,49}$ However, some basal-like tumors do not express this cytokeratin. Additionally, the expression of CK5 is observed in some non-TNBCs. ${ }^{48-50}$ In our study, we have observed CK5 positivity in $10 \%$ of luminal $\mathrm{A}$, in $5 \%$ of luminal B, and in $12.5 \%$ of HER2-enriched IDCs, and we have demonstrated that only $33 \%$ of CK5+ tumors have a mesenchymal phenotype as defined by the positive expression of VIM and the reduction or absence of $\mathrm{CDH} 1$ expression ( $\mathrm{VIM}+/ \mathrm{CDH} 1^{\text {low/- }}$ phenotype).

In our study, a VIM $+/ \mathrm{CDH} 1^{\text {low/- }}$ phenotype was identified in $17.8 \%$ of IDCs, and this phenotype was observed only in TNBCs. We have found some features that classify the $\mathrm{VIM}+/ \mathrm{CDH} 1^{\text {low } /-}$ phenotype as an aggressive IDC. These tumors exhibit a high Ki67 index, are generally poorly differentiated, and have a reduced incidence of lymph node metastasis, suggesting that they display a mesenchymal type of malignant tumor behavior.

Triple negative tumors are associated with a poor prognosis. In fact, some reports have demonstrated that there is a bipolar biological behavior among TNBC patients. There is a group of TNBC patients that develop early and aggressive recurrence, while other TNBC patients present with a more favorable prognosis. ${ }^{51-53}$ Our results suggest that the use of mesenchymal markers may be important to identify TNBC tumors associated with a poor outcome. In fact, we have observed that patients with the $\mathrm{VIM}^{+} / \mathrm{CDH} 1^{-/ \text {low }}$ phenotype have a higher rate of recurrence and a worse prognosis than patients with the TNBC non- $-\mathrm{VIM}^{+} / \mathrm{CDH} 1^{-/ \text {low }}$ phenotype. However, this is a retrospective and single institution study including a relatively small number of samples. A large prospective study is necessary to confirm our findings.

\section{Conclusion}

In conclusion, the IHC identification of a subset of IDC with mesenchymal phenotype suggests the selection of an aggressive IDC subtype and should prompt further investigation on this field.

\section{Contributions}

Tiezzi D. G. participated in the design of the study, in the elaboration of the draft of the manuscript and performed the statistical analysis. Andrade J. M. and Reis F.J.C. participated in the design and in the coordination of the study and helped to elaborate the draft of the manuscript. Tiezzi M.G. performed the immunohistochemical analysis. Bosland M. and Deaton R. were responsible for the digital analysis. Orlandini L. F. contributed in the elaboration of the draft of the manuscript. Silveira W. A. contributed with the data collection and with the selection of the paraffin blocks.

Conflicts of Interest

The authors have no conflicts of interest to declare.

\section{Acknowledgments}

Digital image services were provided by the Research Resources Center, Research Histology and Tissue Imaging Core, at the University of Illinois, Chicago, established 
with the support of the Vice Chancellor of Research. This work received a grant from Fundação de Amparo à Pesquisa do Estado de São Paulo (FAPESP, in the Portuguese acronym), under the grant number 2008/09294-9.

\section{References}

1 Perou CM, Sørlie T, Eisen MB, et al. Molecular portraits of human breast tumours. Nature 2000;406(6797):747-752 Doi: 10.1038/ 35021093

2 Herschkowitz JI, Simin K, Weigman VJ, et al. Identification of conserved gene expression features between murine mammary carcinoma models and human breast tumors. Genome Biol 2007; 8(05):R76 Doi: 10.1186/gb-2007-8-5-r76

3 Fan C, Oh DS, Wessels L, et al. Concordance among gene-expression-based predictors for breast cancer. N Engl J Med 2006;355 (06):560-569 Doi: 10.1056/NEJMoa052933

4 Taube JH, Herschkowitz JI, Komurov K, et al. Core epithelial-tomesenchymal transition interactome gene-expression signature is associated with claudin-low and metaplastic breast cancer subtypes. Proc Natl Acad Sci U S A 2010;107(35):15449-15454 Doi: $10.1073 /$ pnas. 1004900107

5 Perou CM. Molecular stratification of triple-negative breast cancers. Oncologist 2011;16(Suppl 1):61-70 Doi: 10.1634/theoncologist.2011-S1-61

6 Prat A, Pineda E, Adamo B, et al. Clinical implications of the intrinsic molecular subtypes of breast cancer. Breast 2015;24 (Suppl 2):S26-S35 Doi: 10.1016/j.breast.2015.07.008

7 Nielsen TO, Hsu FD, Jensen K, et al. Immunohistochemical and clinical characterization of the basal-like subtype of invasive breast carcinoma. Clin Cancer Res 2004;10(16):5367-5374 Doi: 10.1158/1078-0432.CCR-04-0220

8 Livasy CA, Karaca G, Nanda R, et al. Phenotypic evaluation of the basal-like subtype of invasive breast carcinoma. Mod Pathol 2006;19(02):264-271 Doi: 10.1038/modpathol.3800528

9 Subik K, Lee JF, Baxter L, et al. The expression patterns of ER, PR, HER2, CK5/6, EGFR, Ki-67 and AR by immunohistochemical analysis in breast cancer cell lines. Breast Cancer (Auckl) 2010;4:35-41

10 Park S, Koo JS, Kim MS, et al. Characteristics and outcomes according to molecular subtypes of breast cancer as classified by a panel of four biomarkers using immunohistochemistry. Breast 2012;21(01):50-57 Doi: 10.1016/j.breast.2011.07.008

11 Reeder-Hayes KE, Carey LA, Sikov WM. Clinical trials in triple negative breast cancer. Breast Dis 2010;32(1-2):123-136 Doi: 10.3233/BD-2010-0310

12 Fornier M, Fumoleau $\mathrm{P}$. The paradox of triple negative breast cancer: novel approaches to treatment. Breast J 2012;18(01): 41-51 Doi: 10.1111/j.1524-4741.2011.01175.x

13 Zhang WJ, Wang XH, Gao ST, et al. Tumor-associated macrophages correlate with phenomenon of epithelial-mesenchymal transition and contribute to poor prognosis in triple-negative breast cancer patients. J Surg Res 2018;222:93-101 Doi: 10.1016/j. jss.2017.09.035

14 Adamo B, Ricciardi GRR, Ieni A, et al. The prognostic significance of combined androgen receptor, E-Cadherin, Ki67 and CK5/6 expression in patients with triple negative breast cancer. Oncotarget 2017; 8(44):76974-76986 Doi: 10.18632/oncotarget.20293

15 Carvalho FM, Bacchi LM, Santos PP, Bacchi CE. Triple-negative breast carcinomas are a heterogeneous entity that differs between young and old patients. Clinics (Sao Paulo) 2010;65 (10):1033-1036 Doi: 10.1590/S1807-59322010001000019

16 Bertucci F, Finetti P, Cervera N, et al. How basal are triple-negative breast cancers? Int J Cancer 2008;123(01):236-240 Doi: 10.1002/ ijc.23518

17 Prat A, Perou CM. Deconstructing the molecular portraits of breast cancer. Mol Oncol 2011;5(01):5-23 Doi: 10.1016/j. molonc.2010.11.003
18 Cheang MC, Voduc D, Bajdik C, et al. Basal-like breast cancer defined by five biomarkers has superior prognostic value than triplenegative phenotype. Clin Cancer Res 2008;14(05):1368-1376 Doi: 10.1158/1078-0432.CCR-07-1658

19 Rakha EA, El-Sayed ME, Green AR, Paish EC, Lee AH, Ellis IO. Breast carcinoma with basal differentiation: a proposal for pathology definition based on basal cytokeratin expression. Histopathology 2007;50(04):434-438 Doi: 10.1111/j.1365-2559.2007.02638.x

20 Bhargava R, Beriwal S, McManus K, Dabbs DJ. CK5 is more sensitive than CK5/6 in identifying the "basal-like" phenotype of breast carcinoma. Am J Clin Pathol 2008;130(05):724-730 Doi: 10.1309/AJCP3KFF1LTYWQIY

21 De Brot M, Soares FA, Stiepcich MM, Cúrcio VS, Gobbi H. [Basallike breast cancers: clinicopathological features and outcome]. Rev Assoc Med Bras (1992) 2009;55(05):529-534 Doi: 10.1590/ S0104-42302009000500014

22 Ren X, Yuan L, Shen S, Wu H, Lu J, Liang Z. c-Met and ER $\beta$ expression differences in basal-like and non-basal-like triplenegative breast cancer. Tumour Biol 2016;37(08):11385-11395 Doi: 10.1007/s13277-016-5010-5

23 Sarrió D, Rodriguez-Pinilla SM, Hardisson D, Cano A, MorenoBueno G, Palacios J. Epithelial-mesenchymal transition in breast cancer relates to the basal-like phenotype. Cancer Res 2008;68 (04):989-997 Doi: 10.1158/0008-5472.CAN-07-2017

24 Marchini C, Montani M, Konstantinidou G, et al. Mesenchymal/ stromal gene expression signature relates to basal-like breast cancers, identifies bone metastasis and predicts resistance to therapies. PLoS One 2010;5(11):e14131 Doi: 10.1371/journal.pone.0014131

25 Prat A, Parker JS, Karginova O, et al. Phenotypic and molecular characterization of the claudin-low intrinsic subtype of breast cancer. Breast Cancer Res 2010;12(05):R68 Doi: 10.1186/bcr2635

26 Choi YL, Oh E, Park S, et al. Triple-negative, basal-like, and quintuplenegative breast cancers: better prediction model for survival. BMC Cancer 2010;10:507 Doi: 10.1186/1471-2407-10-507

27 Kokkinos MI, Wafai R, Wong MK, Newgreen DF, Thompson EW, Waltham M. Vimentin and epithelial-mesenchymal transition in human breast cancer-observations in vitro and in vivo. Cells Tissues Organs 2007;185(1-3):191-203 Doi: 10.1159/000101320

28 Singhai R, Patil VW, Jaiswal SR, Patil SD, Tayade MB, Patil AV. ECadherin as a diagnostic biomarker in breast cancer. N Am J Med Sci 2011;3(05):227-233 Doi: 10.4297/najms.2011.3227

29 Liu F, Gu LN, Shan BE, Geng CZ, Sang MX. Biomarkers for EMT and MET in breast cancer: An update. Oncol Lett 2016;12(06):4869-4876 Doi: 10.3892/ol.2016.5369

$30 \mathrm{Wu}$ Y, Sarkissyan M, Vadgama JV. Epithelial-mesenchymal transition and breast cancer. J Clin Med 2016;5(02):E13 Doi: 10.3390/ jcm5020013

31 Zeisberg M, Neilson EG. Biomarkers for epithelial-mesenchymal transitions. J Clin Invest 2009;119(06):1429-1437 Doi: 10.1172/ JCI36183

32 Bindels S, Mestdagt M, Vandewalle C, et al. Regulation of vimentin by SIP1 in human epithelial breast tumor cells. Oncogene 2006;25 (36):4975-4985

33 Raymond WA, Leong ASY. Vimentin-a new prognostic parameter in breast carcinoma? J Pathol 1989;158(02):107-114 Doi: 10.1002/path.1711580205

34 Allred DC, Harvey JM, Berardo M, Clark GM. Prognostic and predictive factors in breast cancer by immunohistochemical analysis. Mod Pathol 1998;11(02):155-168

35 Kim SR, PaikS. Genomics of adjuvant therapy for breast cancer. Cancer J 2011;17(06):500-504 Doi: 10.1097/PPO.0b013e31823e5370

36 Krijgsman O, Roepman P, Zwart W, et al. A diagnostic gene profile for molecular subtyping of breast cancer associated with treatment response. Breast Cancer Res Treat 2012;133(01):37-47 Doi: 10.1007/s10549-011-1683-z

37 Rodler E, Korde L, Gralow J. Current treatment options in triple negative breast cancer. Breast Dis 2010;32(1-2):99-122 Doi: 10.3233/BD-2010-0304 
38 Gelmon K, Dent R, Mackey JR, Laing K, McLeod D, Verma S. Targeting triple-negative breast cancer: optimising therapeutic outcomes. Ann Oncol 2012;23(09):2223-2234 Doi: 10.1093/ annonc/mds067

39 Peddi PF, Ellis MJ, Ma C. Molecular basis of triple negative breast cancer and implications for therapy. Int J Breast Cancer 2012; 2012:217185

40 Walsh S, Flanagan L, Quinn C, et al. mTOR in breast cancer: differential expression in triple-negative and non-triple-negative tumors. Breast 2012;21(02):178-182 Doi: 10.1016/j.breast.2011.09.008

41 Yu M, Bardia A, Wittner BS, et al. Circulating breast tumor cells exhibit dynamic changes in epithelial and mesenchymal composition. Science 2013;339(6119):580-584 Doi: 10.1126/science.1228522

42 Hamilton DH, David JM, Dominguez C, Palena C. Development of cancer vaccines targeting brachyury, a transcription factor associated with tumor epithelial-mesenchymal transition. Cells Tissues Organs 2017;203(02):128-138 Doi: 10.1159/000446495

43 Siletz A, Schnabel M, Kniazeva E, et al. Dynamic transcription factor networks in epithelial-mesenchymal transition in breast cancer models. PLoS One 2013;8(04):e57180 Doi: 10.1371/journal.pone.0057180

44 Xiang X, Deng Z, Zhuang X, et al. Grhl2 determines the epithelial phenotype of breast cancers and promotes tumor progression. PLoS One 2012;7(12):e50781 Doi: 10.1371/journal.pone.0050781

45 Fang Y, Chen Y, Yu L, et al. Inhibition of breast cancer metastases by a novel inhibitor of TGF $\beta$ receptor 1 . J Natl Cancer Inst 2013;105 (01):47-58 Doi: 10.1093/jnci/djs485

46 Choi YL, Bocanegra M, Kwon MJ, et al. LYN is a mediator of epithelial-mesenchymal transition and a target of dasatinib in breast cancer. Cancer Res 2010;70(06):2296-2306 Doi: 10.1158/ 0008-5472.CAN-09-3141

47 Hamilton DH, Litzinger MT, Fernando RI, Huang B, Palena C. Cancer vaccines targeting the epithelial-mesenchymal transition: tissue distribution of brachyury and other drivers of the mesenchymal-like phenotype of carcinomas. Semin Oncol 2012;39(03): 358-366 Doi: 10.1053/j.seminoncol.2012.02.005

48 Alshareeda AT, Soria D, Garibaldi JM, et al. Characteristics of basal cytokeratin expression in breast cancer. Breast Cancer Res Treat 2013;139(01):23-37 Doi: 10.1007/s10549-013-2518-x

49 Aguiar FN, Mendes HN, Bacchi CE, Carvalho FM. Comparison of nuclear grade and immunohistochemical features in situ and invasive components of ductal carcinoma of breast. Rev Bras Ginecol Obstet 2013;35(03):97-102 Doi: 10.1590/S0100-72032013000300002

50 Shao MM, Chan SK, Yu AM, et al. Keratin expression in breast cancers. Virchows Arch 2012;461(03):313-322 Doi: 10.1007/ s00428-012-1289-9

51 Montagna E, Maisonneuve P, Rotmensz N, et al. Heterogeneity of triple-negative breast cancer: histologic subtyping to inform the outcome. Clin Breast Cancer 2013;13(01):31-39 Doi: 10.1016/j. clbc.2012.09.002

52 Yu KD, Zhu R, Zhan M, et al. Identification of prognosis-relevant subgroups in patients with chemoresistant triple-negative breast cancer. Clin Cancer Res 2013;19(10):2723-2733 Doi: 10.1158/ 1078-0432.CCR-12-2986

53 Asaga S, Kinoshita T, Hojo T, Suzuki J, Jimbo K, Tsuda H. Prognostic factors for triple-negative breast cancer patients receiving preoperative systemic chemotherapy. Clin Breast Cancer 2013;13 (01):40-46 Doi: 10.1016/j.clbc.2012.09.013 